\title{
Analisis Nilai Proksimat Kulit Buah Pisang Tongka Langit (Musa troglodytarum L.) Pada Beberapa Tingkat Kematangan Buah
}

\section{Proximate Value Analysis of Tongka Langit Banana Peel Fruit (Musa troglodytarum L.) on some Maturity Fruit Levels}

\section{Deli Wakano*, Dece E. Sahertian, Tati Telussa}

\author{
Jurusan Biologi, Fakultas Matematika dan Ilmu Pengetahuan Alam, Universitas Pattimura \\ Jl. Ir. M. Putuhena, Kampus Poka, Ambon 97233, Maluku, Indonesia
}

*Penulis Korespondensi: Deli Wakano, E-mail: delly_wakano@yahoo.co.id

Tanggal submisi: 15 Juni 2020; Tanggal penerimaan: 15 September 2020

\begin{abstract}
The nutritional content of banana fruit peel is complete, such as carbohydrates, fats, proteins, calcium, phosphorus, iron, vitamin $B$, vitamin $C$, and water. These nutrients can be used as a source of energy and antibodies to the human body. A significant amount of banana peel will result from the home industry and factory when the banana is processed. The peel's ratio to the flesh of the banana is 1.2:1.6. Hence it should be considered for its further utilization. If the peel is not utilized correctly, it will be a source of pollutants. This study aimed to determine the proximate value of the tongka langit banana peel fruit at several maturity stages. The results showed that the tongka langit banana's unripe peel had a protein, fat, and carbohydrate content of $0.49 \%, 1.33 \%$, and $3.23 \%$. At the physiologically ripen stage, the peel had a protein value of $0.62 \%$, fat of $1.68 \%$, and carbohydrate of $3.23 \%$, while for the peel of ripening fruit had a protein value of $0.86 \%$, fat of $1.80 \%$, and carbohydrate of $4.88 \%$. The more ripen is the tongka langit banana fruit, the higher was the protein, fat, and carbohydrate content of the peel.
\end{abstract}

Keywords: maturity fruit level, peel fruit, tongka langit banana

\begin{abstract}
ABSTRAK
Kandungan gizi kulit buah pisang cukup lengkap, seperti karbohidrat, lemak, protein, kalsium, fosfor, zat besi, vitamin $B$, vitamin $C$ dan air. Unsur-unsur gizi inilah yang dapat digunakan sebagai sumber energi dan antibodi bagi tubuh manusia. Pengolahan daging buah pisang sebagai produk olahan makanan pada industri rumahan maupun pabrik, dan tentu saja dari hasil produksi ini akan meninggalkan kulit buah pisang yang sangat banyak. Dengan jumlah produksi dan konsumsi buah pisang yang banyak akan menghasilkan kulit buah pisang yang banyak pula. Perbandingan antara kulit dan daging adalah 1,2:1,6 sehingga perlu dipikirkan pemanfaatannya. Kulit buah pisang yang tidak dimanfaatkan dan diberdayakan dengan benar akan menjadi sumber pencemar. Tujuan dari penelitian ini adalah untuk mengetahui nilai proksimat kulit buah pisang tongka langit (Musa troglodytarum L.) pada beberapa tingkat kematangan buah. Hasil yang dicapai adalah pada kulit buah pisang tongka langit mentah memiliki nilai protein sebesar $0,49 \%$, lemak sebesar 1,33\% dan karbohidrat sebesar 3,23\%. Pada kulit buah pisang tongka langit mengkal memiliki kandungan protein sebesar $0,62 \%$, lemak sebesar 1,68\% dan karbohidrat sebesar 3,23\%, sedangkan untuk kulit buah pisang tongka langit matang memiliki kandungan protein sebesar $0,86 \%$, lemak $1,80 \%$ dan karbohidrat sebesar 4,88\%. Semakin matang buah pisang tongka langit, maka kandungan proksimat (protein, lemak dan karbohidrat) juga semakin tinggi.
\end{abstract}

Kata Kunci: kulit buah, pisang tongka langit, tingkat kematangan buah 


\section{PENDAHULUAN}

Maluku merupakan dengan kepulauan dengan salah satu potensi pisang yaitu pisang tongka langit (Musa troglodytarum L.). Pisang tongka langit memiliki ciri khas yakni tandannya tegak menengadah ke langit. Ini merupakan salah satu ciri yang membedakan pisang tersebut dengan jenis pisang lainnya (Tuhumury et al., 2018). Selain itu, pisang tongka langit memiliki batang yang tidak terlalu berbeda dengan pisang pada umumnya yaitu memiliki tinggi 2-3 m dengan warna hijau, memiliki daun tegak. Buah yang dihasilkan memiliki warna hijau apabila belum cukup matang dan akan memiliki warna merah-orange apabila sudah cukup matang (Hiariej et al., 2015).

Pisang tongka langit biasanya dikonsumsi secara langsung sebagai buah segar atau diolah dengan cara dibakar, dikukus, dan direbus serta dapat dijadikan produk olahan biskuit (Mailoa, 2013), bubur instan (Picauly dan Tetelepta, 2015), crackers (Picauly dan Tetelepta, 2016), brownies (Moniharapon et al., 2018), pati (Palijama et al., 2020) dan beberapa produk lainnya. Pemanfaatan daging buah pisang untuk diolah menjadi berbagai makanan akan menghasilkan limbah berupa kulit pisang (Wakano et al., 2020). Kulit pisang adalah merupakan bahan buangan (limbah buah pisang) yang cukup banyak jumlahnya. Pada umumnya kulit pisang belum dimanfaatkan secara nyata, hanya dibuang sebagai limbah organik saja atau digunakan sebagai makanan ternak seperti kambing, sapi, dan kerbau. Jumlah kulit pisang yang cukup banyak akan memiliki nilai jual yang menguntungkan apabila bisa dimanfaatkan sebagai bahan baku makanan. Kandungan unsur gizi kulit pisang cukup lengkap, seperti karbohidrat, lemak, protein, kalsium, fosfor, zat besi, vitamin B, vitamin $\mathrm{C}$ dan air. Unsur-unsur gizi inilah yang dapat digunakan sebagai sumber energi dan antibodi bagi tubuh manusia (Wilar et al., 2014).

Selain itu, penelitian terdahulu juga menunjukkan bahwa limbah kulit pisang mengandung zat gizi yang cukup tinggi terutama vitamin dan mineralnya sehingga dapat dimanfaatkan sebagai bahan baku makanan. Kulit pisang memiliki kandungan air 68,9 g, karbohidrat $18,5 \mathrm{~g}$, protein $0,32 \mathrm{~g}$, lemak $2,11 \mathrm{~g}$, kalsium 715 $\mathrm{mg}$, fosfor $117 \mathrm{mg}$, besi $1,6 \mathrm{mg}$, vitamin B $0,12 \mathrm{mg}$, dan vitamin C 17,5 mg (Suprapti, 2005). Kandungan gizi kulit buah pisang yang cukup lengkap ini maka perlu adanya pengelolaan yang baik sehingga dapat meminimalisir pencemaran lingkungan akibat sampah dan sebagai alternatif produk pangan ramah lingkungan dan dapat bernilai tambah dalam menunjang perekonomian masyarakat, dari segi pendapatan dan mengurangi biaya kebutuhan rumah tangga (Wakano et al., 2016). Kulit buah pisang yang tidak dimanfaatkan dan diberdayakan dengan benar akan menjadi sumber pencemar (Hartono dan Pramudyo, 2013).

Berdasarkan data tersebut, maka perlu dilakukan analisis terhadap kulit buah pisang tongka langit pada beberapa tingkat kematangan buah, sehingga potensi kulit buah pisang tongka langit dapat dimanfaatkan dengan baik. Tujuan dari penelitian ini adalah untuk mengetahui nilai proksimat kulit buah pisang tongka langit (Musa troglodytarum L.) pada beberapa tingkat kematangan buah.

\section{METODE PENELITIAN}

\section{Bahan}

Buah pisang tongka langit dengan ukuran panjang berasal dari Desa Hutumuri, Kecamatan Leitimur Selatan, Kota Ambon, berdasarkan tingkat kematangan. Tingkat kematangan buah yang dipilih yaitu (indeks 1) yang merupakan buah pisang yang masih mentah dengan warna kulit buah hijau, (indeks 5) buah pisang yang matang dengan warna kulit buah kuning lebih banyak dari pada hijau dan (indeks 8) buah pisang yang lewat matang dengan warna kulit buah kuning dengan bercak coklat lebih luas (Gambar 2).

Bagian kulit pisang berdasarkan tingkat kematangan tesebut digunakan sebagai bahan penelitian. Bahan-bahan kimia lainnya yang digunakan adalah pure analysis.

\section{Penyiapan sampel}

Buah pisang dikupas kemudian bagian kulitnya diambil $100 \mathrm{~g}$ dipotong menjadi bagian kecil-kecil, kemudian dikeringkan menggunakan oven pada suhu $60^{\circ} \mathrm{C}$ selama 6 jam. Kulit pisang yang telah kering kemudian disimpan dalam wadah kedap air sampai digunakan untuk analisis.

\section{Analisis Protein Kulit Pisang (AOAC, 1999)}

Kulit buah pisang tongka langit kering sebanyak 0,51 g sampel dimasukkan ke labu Kjeldahl dan ditambahkan $2 \mathrm{~g}$ campuran selenium dan $25 \mathrm{~mL} \mathrm{H}_{2} \mathrm{SO}_{4}$ pekat. Semua bahan didestruksi dalam labu Kjeldahl di atas pemanas listrik sampai 
mendidih dan larutan menjadi jernih kehijauhijauan (sekitar 2 jam). Larutan diencerkan dengan $25 \mathrm{~mL}$ akuades dan didinginkan sampai suhu kamar. Larutan sebanyak $15 \mathrm{~mL}$ dimasukan ke dalam alat penyuling lalu ditambahkan $15 \mathrm{~mL}$ $\mathrm{NaOH} 30 \%$ dan beberapa tetes indikator fenolftalein. Penyulingan selama lebih kurang 10 menit. Uap ditampung di Erlenmeyer yang berisi asam borat $2 \%$ yang telah dicampur indikator. Destilat yang diperoleh dititrasi dengan $\mathrm{HCl} 0,01 \mathrm{~N}$. Titik akhir titrasi ditandai dengan terjadinya perubahan warna biru menjadi merah muda. Dilakukan juga penetapan blanko.

$$
\text { Kadar Protein }=\frac{\left(V_{1}-V_{2}\right) \times N \times 0,014 \times f k \times f p}{W}
$$

dimana: $V_{1}=$ volume $\mathrm{HCl} 0,01 \mathrm{~N}$ (sampel); $V_{2}=$ volume $\mathrm{HCl}$ (blanko); $\mathrm{N}=$ normalitas $\mathrm{HCl}$; fk = faktor koreksi buah-buahan $=6,25$; $\mathrm{fp}=$ faktor pengenceran; $\mathrm{W}=$ bobot sampel.

\section{Penentuan kadar lemak}

Analisis kadar lemak menggunakan metode Soxhlet menurut Sudarmadji et al. (1989). Sebanyak 2 g sampel dibungkus dengan kertas saring, kemudian ditutup dengan kapas wool yang bebas lemak. Sampel dikeringkan dalam oven pada suhu tidak lebih dari $80^{\circ} \mathrm{C}$ selama kurang lebih satu jam. Kemudian kertas saring yang berisi sampel tersebut dimasukkan dalam alat ektraksi soxhlet, kemudian dipasang alat kondensor diatasnya dan labu lemak berisi batu didih yang telah dikeringkan di bawahnya. Pelarut heksana dituangkan ke dalam labu lemak secukupnya sesuai dengan ukuran yang digunakan. Selanjutnya dilakukan refluks minimum 6 jam sampai pelarut yang turun kembali ke labu lemak berwarna jernih. Pelarut yang ada di dalam labu lemak didestilasi dan ditampung. Labu lemak yang berisi hasil ekstraksi dipanaskan dalam oven pada suhu $105^{\circ} \mathrm{C}$ kemudian didinginkan dalam desikator dan dilakukan penimbangan hingga diperoleh bobot tetap.

$\%$ Lemak $=\frac{\text { bobot lemak sebelum ekstraksi }- \text { bobot lemak sesudah ekstraksi }}{}$

\section{Penetapan kadar karbohidrat}

Prosedur analisis karbohidrat kulit pisang menurut International Starch Institute (2002) adalah sebagai berikut. Kulit buah pisang tongka langit kering sebanyak 5 g sampel dilarutkan dalam $200 \mathrm{~mL} \mathrm{HCl}$ $3 \%$ kemudian dididihkan selama 3 jam. Selanjutnya didinginkan dan dinetralkan dengan larutan $\mathrm{NaOH}$ $30 \%$ dan ditambahkan sedikit $\mathrm{CH}_{3} \mathrm{COOH} 3 \%$ agar suasana larutan agar sedikit asam.
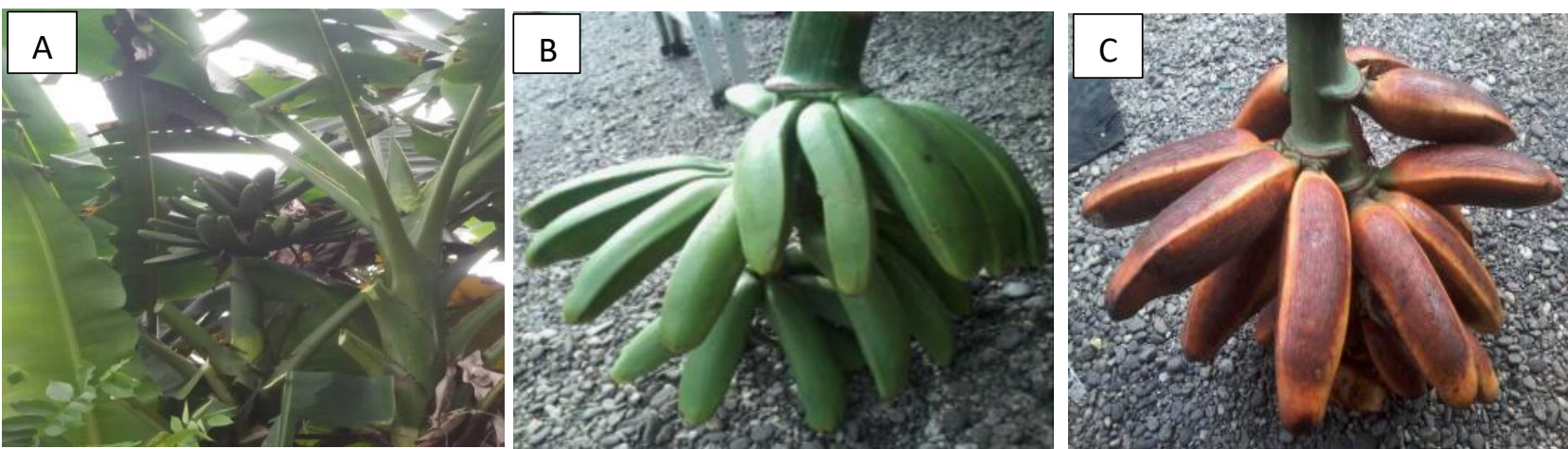

Gambar 1. Tanaman pisang tongka langit (Musa troglodytarum L): A) pohon pisang tongka langit; B) buah pisang tongka langit mentah; dan C) Buah pisang tongka langit matang. Sumber: Dokumentasi Pribadi
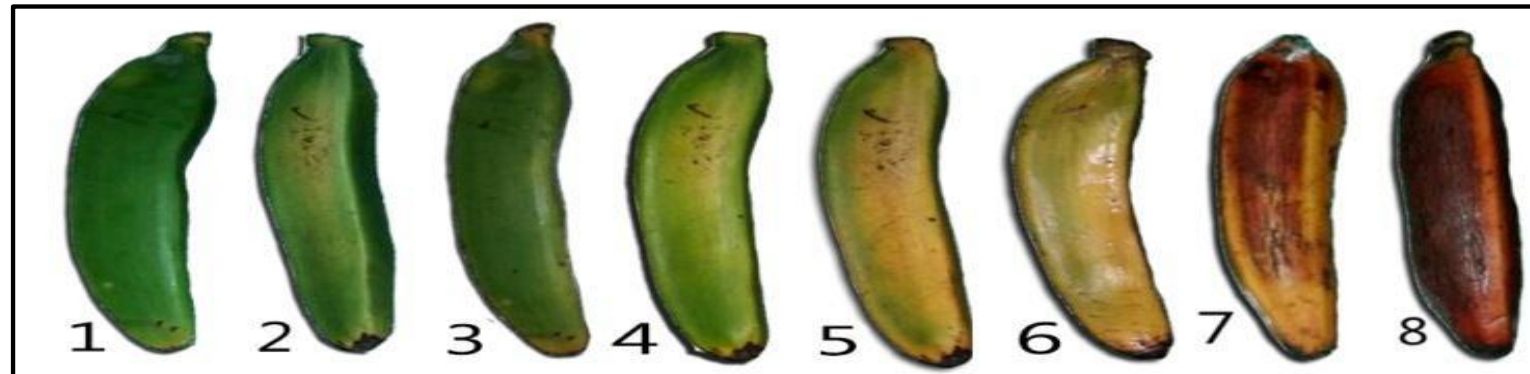

Gambar 2. Tingkat kematangan buah sesuai indeks warna kulit buah. Sumber : Dokumentasi pribadi. 
Semuanya dipindahkan ke labu ukur $500 \mathrm{~mL}$ dan ditambahkan $25 \mathrm{~mL}$ larutan Luff-Schoorl, beberapa butir batu didih dan $15 \mathrm{~mL}$ akuades. Kemudian campuran tadi dipanaskan selama 10 menit. Setelah dingin, ditambahkan $15 \mathrm{~mL}$ larutan KI 20\% dan $25 \mathrm{~mL} \mathrm{H}_{2} \mathrm{SO}_{4} 25 \%$ secara perlahanlahan. Titrasi secepatnya dengan larutan tiosulfat $0,1 \mathrm{~N}$ yang ditandai dengan perubahan warna kuning muda lalu ditambahkan 3 tetes indikator pati dan titrasi dilanjutkan sampai titik akhir yang ditandai dengan perubahan warna dari biru kehitamanan menjadi tidak berwarna. Prosedur ini berlaku pula untuk blanko dengan mengganti sampel dengan air akuades. Perhitungan kadar glukosa mengikuti rumus berikut ini:

$$
\text { Kadar Glukosa }=\frac{W_{1} \times f p}{W} \times 100 \%
$$

Kadar Karbohidrat $=0,90 \times$ kadar glukosa dimana $: f p=$ faktor pengenceran; $W=$ bobot sampel $(\mathrm{mg}) ; W_{1}=$ bobot glukosa $(\mathrm{mg})\left(W_{1}\right.$ adalah $\left(V_{2}-V_{1}\right)$ yang dikonversi menjadi berat (mg) glukosa menggunakan tabel Luff-Schoorl.

\section{Analisis Statistika}

Penelitian ini menggunakan rancangan acak lengkap (RAL) dengan tiga taraf perlakuan tingkat kematangan buah yaitu pertama untuk kategori mentah (indeks 1: warna kulit hijau), kedua untuk kategori matang (indeks 5: warna kuning dengan ujung berwarna hijau), dan ketiga kategori lewat matang (indeks 8: warna kuning dengan bercak coklat lebih luas). Masing-masing taraf perlakuan diulang sebanyak tiga kali (Caussiol, 2001).

\section{HASIL DAN PEMBAHASAN}

Hasil analisis kandungan protein, lemak dan karbohidrat pada kulit buah pisang tongka langit mentah, matang dan lewat matang dapat dilihat pada Tabel 1 .

Berdasarkan hasil pada tabel 1 menunjukkan bahwa nilai protein pada kulit buah pisang tongka langit lewat matang bernilai $0,86 \%$ lebih tinggi jika dibandingkan dengan nilai protein pada kulit buah pisang mentah dan matang. Nilai lemak $1,80 \%$ pada kulit buah pisang tongka langit lewat matang lebih tinggi dari tingkat kematangan mentah dan matang. Sama halnya dengan nilai karbohidrat 4,88\% pada kematangan lewat matang lebih tinggi nilainya dari tingkat kematangan mentah dan matang kulit buah pisang tongka langit. Hal ini menunjukkan bahwa tingkat kematangan mempengaruhi kandungan proksimat pada kulit buah pisang tongka langit, semakin matang buah pisang tongka langit maka nilai proksimatnya juga semakin tinggi. Perubahan akan terus terjadi selama proses pemasakan. Sebagaimana menurut Sumadi (2004) bahwa meningkatnya aktivitas respirasi pada buah klimakterik merupakan aktivitas fisiologis yang terjadi pada saat proses pemasakan buah pisang. Selanjutnya ditambahkan oleh Morris et al. (2004), kandungan gizi pada tumbuhan dipengaruhi oleh genetik tanaman, kondisi tanah tempat tumbuh, iklim, kondisi fisiologis buah, proses pemanenan (cara pengepakan, kondisi penyimpanan dan cara pengolahannya).

Selanjutnya jika penelitian ini dibandingkan dengan beberapa penelitian terdahulu seperti penelitian Aryani et al. (2018) tentang karakteristik fisik, kandungan gizi tepung kulit pisang dan perbandingannya terhadap syarat mutu tepung terigu menunjukkan perbedaan yang cukup signifikan. Dimana hasil yang didapatkan adalah protein $7,16 \%$, lemak $6,37 \%$ dan karbohidrat $76,20 \%$. Namun hal ini berbeda juga dengan penelitian Suprapti (2005) yang menunjukkan bahwa kulit pisang mengandung protein $0,32 \%$, lemak $2,11 \%$ dan karbohidrat $18,5 \%$. Penelitian Ermawati et al. (2016) menunjukan bahwa kulit pisang raja mengandung protein $0,94 \%$, lemak $0,07 \%$ dan karbohidrat $10,67 \%$. Penelitian Pary et al. (2016) menunjukkan kulit pisang kepok mentah mengandung protein $1,83 \%$, matang $1,84 \%$, lemak kulit pisak kepok mantah 2,87 \%, matang 3,16\%, dan mentah mengandung karbohidrat $10 \%$, dan matang $14 \%$. Dari beberapa penelitian terdahulu tersebut menunjukkan bahwa terdapat perbedaan kandungan gizi kulit pisang antara penelitian satu dengan penelitian lainnya. Hal ini diduga disebabkan karena umur panen yang berbeda, jenis pisang yang berbeda dan proses denaturasi. Menurut Supriadi et al., (2008) bahwa perubahan kandungan pada buah akan meningkat pada saat pertumbuhan mencapai $80 \%$ masa pertumbuhannya dan setelah itu akan menurun. Selain itu, menurut Palupi (2012) bahwa jenis pisang memberikan pengaruh nyata pada kandungan gizi pisang. Selanjutnya ditambahkan oleh Dewi et al., (2017) bahwa perbedaan kandungan gizi pada kulit pisang disebabkan oleh perbedaan spesies pada pisang yang digunakan. 
Tabel 1. Hasil analisis kandungan proksimat pada kulit buah pisang tongka langit

\begin{tabular}{lcccc}
\hline \multirow{2}{*}{ Parameter } & \multicolumn{3}{c}{ Tingkat Kematangan } & \multirow{2}{*}{ Standar Acuan } \\
\cline { 2 - 4 } & Mentah & Matang & Lewat Matang & \\
Protein $(\%)$ & 0,49 & 0.62 & 0,86 & SNI 01 - 2891 - 1992 \\
Lemak $(\%)$ & 1,33 & 1,68 & 1,80 & \\
Karbohidrat (\%) & 3,23 & 4,40 & 4,88 & \\
\hline
\end{tabular}

\section{KESIMPULAN}

Nilai protein pada kulit buah pisang tongka langit lewat matang bernilai 0,86\% lebih tinggi jika dibandingkan dengan nilai protein pada kulit buah pisang mentah dan matang. Nilai lemak $1,80 \%$ pada kulit buah pisang tongka langit lewat matang lebih tinggi dari tingkat kematangan mentah dan matang. Sama halnya dengan nilai karbohidrat $4,88 \%$ pada kematangan lewat matang lebih tinggi nilainya dari tingkat kematangan mentah dan matang kulit buah pisang tongka langit. Hal ini menunjukkan bahwa tingkat kematangan mempengaruhi kandungan proksimat pada kulit buah pisang tongka langit, semakin matang buah pisang tongka langit maka nilai proksimatnya juga semakin tinggi.

\section{DAFTAR PUSTAKA}

AOAC. 1999. Official Methods of Analysis of AOAC International. Ed. Ke-8. Maryland: AOAC International.

Aryani, T., I.A.U. Mu'awanah, dan A.B. Widyantara. 2018. Karakteristik fisik, kandungan gizi tepung kulit pisang dan perbandingannya terhadap syarat mutu tepung terigu. Jurnal Riset Sains dan Teknologi 2: 45-50.

Caussiol, L. 2001. Postharvest Quality Conventional And Organically Grown Banana fruit. Master of Science by Research in Postharvest Technology. Institute of Agriculture of Agritecnology. Cranfield University. Silsoe, 160.

Dewi, V.R., A. Nugroho, dan S. Putri. 2017. Pengaruh penambahan kacang merah terhadap sifat organoleptik, kandungan kalsium dan protein pada produk sari kulit pisang. Jurnal Kesehatan Holistik 11: 42-52.

Ermawati, W.O., S. Wahyuni, dan S. Rejeki. 2016. Kajian pemanfaatan limbah kulit pisang raja (Musa paradisiaca var Raja) dalam pembuatan es krim. Jurnal Sains dan Teknologi Pangan 1: 67-72.
Hartono, A. dan B. Pramudyo. 2013. Pelatihan pemanfaatan limbah kulit pisang sebagai bahan dasar pembuatan kerupuk. Seri Pengabdian Masyarakat 2: 198-203.

Hiariej, A., E.L. Arumingtyas, W. Widoretno, and R. Azrianingsih. 2015. Phenotypic variation of fei banana (Musa troglodytarum L.) originated from Maluku Islands. Research Journal of Pharmaceutical, Biological and Chemical Sciences 6: 652-658.

International Starch Institute. 2002. Denmark International Standard: ISO 5377ISI 28-1e Determination of Reducing Sugar, DE by Luff-Schoorl's method. Science Park Aarhus, Copenhagen.

Mailoa, M. 2012. Pengembangan pisang tongka langit (Musa troglodytarum) menjadi biskuit. Jurnal Ekologi dan Sains 1: 6-13.

Moniharapon, E., L. Lelmalaya, dan P. Picauly. 2018. Kajian sifat kimia dan organoleptik brownies pisang tongka langit. AGRITEKNO Jurnal Teknologi Pertanian 7: 60-63. DOI: 10.30598/jagritekno.2018.7.2.60

Morris, W.L., L. Ducreux, D.W. Griffiths, D. Stewart, H.V. Davies, and M.A. Taylor. 2004. Carotenogenesis during tuber development and storage in potato. Journal of Experimental Botany 399: 975-982. DOI: 10.1093/jxb/erh121

Pary, C., Masita, S. Annisa, N. Maya, dan S. Endang. 2016. Analisis kandungan gizi limbah kulit pisang kepok (Musa paradisiaca Formatypica) sebagai bahan baku kerupuk. Jurnal Biology Science \& Education 5: 112123.

Palijama, S., M. Singkery, R. Breemer, and F.J. Polnaya. 2020. Isolation and characteristics of Musa troglodytarum L. starch at different maturity stage. Journal of Physics: Conference Series 1463: 012015. DOI: 10.1088/1742-6596/1463/1/012015

Palupi, H.T. 2012. Pengaruh jenis pisang dan bahan perendam terhadap karakteristik tepung pisang (Musa spp.). Jurnal Teknologi 


$\begin{array}{lll}\text { Pangan 4: } & \text { 102-120. } & \text { DOI: }\end{array}$

Picauly, P. and G. Tetelepta. 2016. Uji organoleptik crackers pisang tongka langit. AGRITEKNO Jurnal Teknologi Pertanian 5: 53-57. DOI: 10.30598/jagritekno.2016.5.2.53

Picauly, P. dan G. Tetelepta. 2015. Karakteristik kimia bubur instan tersubtitusi tepung pisang tongka langit. Agroforestri 9: 122-126.

Sumadi, B. Sugiharto, dan Suyanto. 2004. Metabolisme sukrosa pada proses pemasakan buah pisang yang diperlakukan pada suhu berbeda. Jurnal Ilmu Dasar 5: 21-26.

Supriyadi, A. dan S. Satuhu. 2008. Pisang, Budidaya, Pengolahan dan Prospek Pasar. Jakarta: Penebar Swadaya.

Suprapti, L.M. 2005. Keripik, Manisan Kering, dan Sirup Nangka. Yogyakarta (ID): Kanisius.

Sudarmadji, S. B. Haryono, dan Suhardi. 1989. Analisa Bahan Makanan dan Pertanian. Yogyakarta: Liberty.
Tuhumury, H.C.D., E. Moniharapon, dan A. Souripet. 2018. Karakteristik sensoris puree pisang tongka langit pendek (Musa troglodytarum). Jurnal Teknologi Pertanian 9: 1-10.

Wakano, D., E. Samson, dan L.D. Tetelepta. 2016. Pemanfaatan limbah kulit pisang sebagai bahan olahan kripik dan kue donat di Desa Batu Merah Kota Ambon. BIOSEL Jurnal Penelitian Science dan Pendidikan 5: 152158

Wilar, G., W. Indriyati, dan A. Subarnas. 2014. Pemanfaatan dan pengolahan limbah kulit pisang menjadi permen kulit Pisang yang berkhasiat antidepresi dalam upaya pemberdayaan kesehatan dan perekonomian masyarakat desa di Kecamatan Karang Tengah Kabupaten Cianjur. Dharmakarya Jurnal Aplikasi Ipteks untuk Masyarakat 3: 58. 